\title{
Muscle Enhancement Product Use
}

National Cancer Institute

\section{Source}

National Cancer Institute. Muscle Enhancement Product Use. NCI Thesaurus. Code C123390.

This is a single item, three part measure taken from the Growing Up Today Study (GUTS) that assesses use and frequency of various products (e.g., creatine, growth hormone, steroids) to improve muscle mass or strength in the past year. 